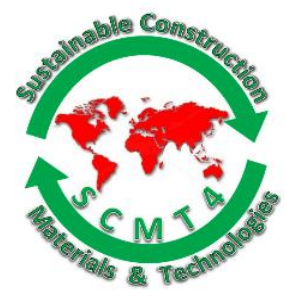

SCMT4

Las Vegas, USA, August 7-11, 2016

\title{
Development of Environmental Impact Tool to Assess the Sustainable Management of Pavements in Poor Condition
}

\author{
Eleanor F. Bloom ${ }^{1 \mathrm{a}}$ and Tuncer B. Edil ${ }^{1 \mathrm{~b}}$ \\ ${ }^{1}$ Recycled Materials Resource Center; University of Wisconsin-Madison, 1415 Engineering Drive, \\ Madison,WI, USA. ${ }^{1 a}$ Email: <efbloom@wisc.edu>, ${ }^{l b}$ Ph.D., P.E., D. GE, Distinguished Member, \\ ASCE, ${ }^{1 b}$ Email: <tbedil@wisc.edu>.
}

\begin{abstract}
In 2014, the Minnesota Department of Transportation (MnDOT) developed a project to analyze the performance, service life, costs, and environmental impact of nine treatment strategies for increasing the sustainability of pavements in poor conditions on Minnesotan roadways. MnDOT's goal was to develop a spreadsheet decision tool for selecting an appropriate treatment for pavements with different physical and operational characteristics. The Recycled Materials Resource Center (RMRC) was tasked with the environmental analysis, and performed a life cycle analysis (LCA) of the nine treatment options using the Pavement Life-cycle Assessment Tool for Environmental and Economic Effects (PaLATE). The treatments addressed initial roadway conditions and incorporated both new and recycled materials. Treatments included entire surface, areal applications (chip seal, double chip seal, micro-surfacing, CapeSeal, UltraThin bonded wear course, 5-cm hot mix asphalt (HMA) overlay, and mill \& 5-cm HMA overlay) and localized applications (mastic for patching and crack sealing). PaLATE assesses the environmental impacts of pavement and road construction based on user inputs of initial design dimensions, initial construction material and processes, maintenance, equipment use, and transportation. In this analysis, four environmental factors output by PaLATE were considered to assess the treatments sustainability: energy, water consumption, $\mathrm{CO}_{2}$ emissions, and RCRA hazardous waste. Roadway lifetimes depended on the type of treatment and the initial severity of the roadway's condition. To account for differing treatment lifetimes, the results were annualized. In general, the magnitude of the environmental impact was proportional to the amount of material required. The localized treatments (mastic patches and crack sealing) required far less material then the areal treatments, thus had a smaller environmental impacts. The 5-cm HMA overlay and mill \& 5-cm HMA overlay required the most material, thus had the greatest environmental impacts. Of the areal applications the chip seal and micro-surfacing had the smallest environmental impacts.
\end{abstract}

\section{INTRODUCTION}

In 2011, the Minnesota Department of Transportation (MnDOT) began an investigation of developing a comprehensive method for evaluating treatment options for extending the service life of pavements in poor condition until they can be rehabilitated (Adams et. al. 2014). The project was tasked with integrating a selection methodology into a spreadsheet-based decision tool with two components: 1) Identification of available treatments and definition of expected service life based on existing pavement distress levels and operational characteristics, 2) A summary of selection factors. Selection actors considered in the overall analysis include: agency cost, agency benefit, user costs during construction, 
safety benefits, and environmental impacts. The Recycled Materials Resource Center (RMRC) was tasked with performing the environmental impact analysis of nine treatment strategies for extending the life of pavements in poor condition. This paper explores the methods and results of the environmental analysis and recommends how their impacts can be incorporated in the decision-making tool.

\section{Background}

MnDOT maintains over 12,000 miles of statehighways that serve, on an average day, over 90 million vehicles (MnDOT 2014). Pavement deterioration is prevalent in the state, and tight budgets and dwindling revenue hinder transportation agencies from fully rehabilitating pavements in poor conditions (Adams et. al., 2014). Consequently, MnDOT sought a research project to determine economical and practical "stop-gap" treatment measures to extend the lifetime their roadways until more affordable solutions are feasible. It was stipulated that treatments would be applied to pavement in poor conditions as determined by a ride quality index, which is based on measured pavement profiles and calculated international roughness index. A spreadsheet-based tool for selecting and analyzing treatment strategies was required. It was intended that the tool will analyze the options based on effectiveness by providing estimates of project-level equivalent annual agency and user costs and environmental impact. Agency costs include the expenditures to build and maintain roadway facilities (DeCorla-Souza et al. 1997). A user cost is defined as the additional costs borne by motorists and the community at-large because of work zone activity (FHWA 2011). These costs, combined with environmental impact assessments, lead to considerations of economic and environmental sustainability in maintaining a healthy road system.

The general work plan for the entire project is as follows (Adams et. al. 2014):

Task 1: Characterize the Pavements in Poor Conditions - Researchers prepared a characterization of MN's roadways in poor conditions. The results of this research was used to define the scope and scale of pavements to be addressed by the treatment methods.

Task 2: Identify and Characterize Treatments for Poor Pavements - A comprehensive list of treatments was developed, including a "do-nothing" scenario and materials (including recycled materials) applicable to pavements in poor conditions.

Task 3: Tool for Recommending Treatments for Pavements in Poor Condition - A spreadsheet tool was created for recommending project-level treatments for pavements in poor condition. This tasks focused on technical feasibility of treatments.

Task 4: Memo Describing Cost Effectiveness Parameters - MnDOT provided domain specific knowledge on the estimated performance, service life, agency cost, and reduced maintenance cost for each treatment. This established the cost effectiveness of alternative treatments.

Task 5: Environmental Impacts Parameters - The basic set of parameters for evaluating the environmental impacts and the unit values of these parameters for each treatment were determined. A recommendation for incorporating the impacts into the tool was also requested. This task was addressed by RMRC and is discussed in this paper.

Task 6: Spreadsheet Tool for Evaluating Cost-Effectiveness and Environmental Impacts - The user guide from Task 3 will be expanded with cost and environmental data from Tasks 4 and 5. The resulting tool is to assist pavement maintenance decision makers in selecting and evaluating alternative treatment methods. The final tool was developed by the National Center for Freight \& Infrastructure Research \& Education -CFIRE (Adams et. al. 2014). 


\section{TREATMENT OPTIONS}

The treatment options were explored in Task 2 and selected prior to the environmental analysis in Task 3 . The considered treatments address initial roadway condition and incorporate both virgin and recycled materials. All volumes of treatment materials were calculated per lane-mile and corresponding thicknesses. In practice many of the treatments are specified on an area basis (i.e. square meters). However, the RMRC analysis tool, PaLATE, required volumes to perform environmental impacts analysis (Horvath, 2007). The considered treatments, their component materials, and the assumed thicknesses are listed in Table 1. MnDOT provided the quantities of component materials, and the CFIRE research team assumed thicknesses (Adams et. al. 2014). These treatments represent some of the more common and researched methods used by MnDOT (Johnson 2003, Janisch and Gaillard 1998). In the final evaluation tool, assumed thicknesses can be adjusted in a supplemental worksheet if needed, and the environmental impacts will be automatically scaled accordingly.

Table 1. List of treatments with their corresponding type and thickness

\begin{tabular}{|c|c|c|c|}
\hline Treatment & Type & Thickness & Components \\
\hline Chip Seal & Areal & $1.3 \mathrm{~cm}$ & $\begin{array}{l}\text { - } 1.1 \mathrm{~L} \text { of chip seal emulsion (CRS-2P) } \\
-0.53 \mathrm{~L} \text { of fog seal emulsion (CSS-1h) } \\
-0.84 \mathrm{~m}^{2}(1 \mathrm{SY}) \text { of aggregate seal coat material }\end{array}$ \\
\hline Double Chip Seal & Areal & $2.5 \mathrm{~cm}$ & $\begin{array}{l}-1.7 \mathrm{~L} \text { of chip seal emulsion (CRS-2P) } \\
\bullet 0.53 \mathrm{~L} \text { of fog seal emulsion (CSS-1h) } \\
-1.7 \mathrm{~m}^{2} \text { (2 SY) of aggregate seal coat material }\end{array}$ \\
\hline Micro-surfacing & Areal & $2.5 \mathrm{~cm}$ & $\begin{array}{l}\text { - } 1.9 \mathrm{~L} \text { of micro-surfacing emulsion }(\mathrm{CSS}-1 \mathrm{~h}) \\
-6.8 \mathrm{~kg} \text { of scratch coarse (aggregate) } \\
\text { - } 6.8 \mathrm{~kg} \text { of micro-surfacing wearing course } \\
\text { (aggregate) }\end{array}$ \\
\hline CapeSeal & Areal & $3.8 \mathrm{~cm}$ &  \\
\hline $\begin{array}{l}\text { UltraThin Bonded } \\
\text { Wear Course }\end{array}$ & Areal & $2.5 \mathrm{~cm}$ & $\begin{array}{l}-0.9 \mathrm{~L} \text { of polymer modified tack coat (CSS-1HP) } \\
\text { - } 3.4 \mathrm{~kg} \text { of HMA, 5.5\% PMA and } 94.5 \% \text { crushed } \\
\text { aggregate }\end{array}$ \\
\hline $\begin{array}{l}\text { 5-cm HMA } \\
\text { Overlay }\end{array}$ & Areal & $5 \mathrm{~cm}$ & $\begin{array}{l}\text { - } 103 \mathrm{~kg} \text { of HMA, } 5.5 \% \text { asphalt binder, } 94.5 \% \\
\text { aggregate (90\% crushed, } 10 \% \text { natural sand) }\end{array}$ \\
\hline $\begin{array}{l}\text { Mill \& 5-cm } \\
\text { HMA Overlay }\end{array}$ & Areal & $5 \mathrm{~cm}$ & $\begin{array}{l}-0.84 \mathrm{~m}^{2}(1 \mathrm{SY}) \text { of milling } 5 \mathrm{~cm} \text { depth } \\
-103 \mathrm{~kg} \text { of HMA, 5.5\% asphalt binder, } 94.5 \% \\
\text { aggregate (90\% crushed, } 10 \% \text { natural sand) }\end{array}$ \\
\hline $\begin{array}{l}\text { Mastic for } \\
\text { Patching }\end{array}$ & Localized & $\begin{array}{c}7.6 \mathrm{~cm} \\
\text { (moderate) } \\
15 \mathrm{~cm} \\
\text { (severe) }\end{array}$ & $\begin{array}{l}\text { - } 42 \mathrm{~kg} \text { of mastic, } 7 \% \text { asphalt binder, } 93 \% \text { fine } \\
\text { aggregate } \\
\text { - } 1.1 \mathrm{~L} \text { of chip seal emulsion (CRS-2P) } \\
\text { - } 0.84 \mathrm{~m}^{2}(1 \mathrm{SY}) \text { of seal coat aggregate }\end{array}$ \\
\hline Crack Sealing & Localized & $15.2 \mathrm{~cm}$ & $\begin{array}{l}-0.84 \mathrm{~m}^{2}(1 \mathrm{SY}) \text { of aggregate (filler) } \\
\bullet 10 \% \text { asphalt by volume }\end{array}$ \\
\hline
\end{tabular}

Additionally, the environmental impact of each treatment is dependent on its lifetime. The estimated service lives of each treatment are listed in Table 2. Each treatment has an estimated minimum and maximum service life that are conditional to the initial state of the pavement, designated as moderate, 
poor, and very poor. Treatment for pavements in moderate condition have longer lifetimes than those in poor conditions. Some of the treatment options are unsuitable if the pavement is in very poor condition.

Table 2. Estimated service lives for treatment options based on pavement condition

\begin{tabular}{|c|l|c|c|c|c|c|c|}
\hline \multirow{2}{*}{} & \multicolumn{3}{c|}{$\begin{array}{c}\text { Minimum Service Life } \\
\text { (Years) }\end{array}$} & \multicolumn{3}{c|}{$\begin{array}{c}\text { Maximum Service Life } \\
\text { (Years) }\end{array}$} \\
\cline { 3 - 8 } Type & Treatment & Moderate & Poor & $\begin{array}{c}\text { Very } \\
\text { Poor }\end{array}$ & Moderate & Poor & $\begin{array}{c}\text { Very } \\
\text { Poor }\end{array}$ \\
\hline Areal & Chip Seal & 4 & 1 & n/a & 5 & 2 & n/a \\
\hline Areal & Double Chip Seal & 5 & 3 & 1 & 6 & 4 & 2 \\
\hline Areal & Microsurfacing & 4 & 2 & 1 & 5 & 3 & 2 \\
\hline Areal & Cape Seal & 5 & 3 & 2 & 6 & 4 & 3 \\
\hline Areal & UltraThin & 6 & 4 & 3 & 7 & 5 & 4 \\
\hline Areal & 5-cm HMA Overlay & 5 & 3 & 3 & 6 & 4 & 4 \\
\hline Areal & Mill \& 5-cm HMA & 6 & 4 & 3 & 7 & 5 & 4 \\
\hline Local & Orack Sealing & 5 & 3 & 1 & 6 & 4 & 2 \\
\hline Local & Mastic & 6 & 4 & 3 & 7 & 5 & 4 \\
\hline
\end{tabular}

\section{ENVIRONMENTAL IMPACT ANALYSIS}

The Pavement Life-cycle Assessment Tool for Environmental and Economic Effects (PaLATE) is a spreadsheet LCA program designed by the Consortium on Green Design and Manufacturing from the University of California, Berkeley for RMRC. PaLATE assesses the environmental and economic effects of pavement and road construction. Users input the initial design, initial construction material, maintenance material, and equipment use for a roadway project. Environmental outputs include (Horvath, 2007): energy consumption (GJ), water consumption $(\mathrm{kg}), \mathrm{CO}_{2}$ emissions $(\mathrm{kg}), \mathrm{NO}_{\mathrm{x}}$ emissions ( $\mathrm{kg}$ ), $\mathrm{PM}_{10}$ emissions ( $\mathrm{kg}$ ), $\mathrm{SO}_{2}$ emissions ( $\mathrm{kg}$ ), $\mathrm{CO}$ emissions $(\mathrm{kg})$, and Leachate information including mercury, lead, Resource Conservation and Recovery Act (RCRA) hazardous waste generated, and both cancerous and non-cancerous human toxicity potential

Four environmental factors for impacts analysis (energy, water consumption, $\mathrm{CO}_{2}$ emissions, and RCRA hazardous waste) were deemed sufficient for evaluation of MnDOT maintenance strategies per the initial MnDOT contract specifications. Although the report does not specify that the analysis is limited to these factors, it was determined that the four categories would provide sufficient representation of a treatment's impact.

The RCRA is a United States law that provides general guidelines for a federal waste management program (U.S. EPA, 2015). Enacted by Congress in 1976 and carried out by the US Environmental Protection Agency's (EPA) Office of Solid Waste, RCRA aims to protect human health and the environment from a diversity of hazardous and nonhazardous wastes. The consideration of RCRA in PaLATE demonstrates the advantages of including regulated substances in assessments (Horvath, 2007).

\section{Assumptions}

The assumptions made to render the provided treatment information compatible with the PaLATE database are provided below.

1) For uniformity, the environmental results were calculated per lane-mile. The provided $0.84 \mathrm{~m}^{2}$ 
(1 SY) amount of material was multiplied to represent that quantity of material required for an area of 1.6 kilometers ( 1 mile) by one lane. One lane was assumed to be 3.6 meters wide.

2) Palate required volumes of materials for its analysis. The materials for one lane-mile were multiplied by the treatments' appropriate thickness (Table 1) to calculate the volume of material require for one lane-mile.

3) For localized treatments (mastic patching and crack sealing), the extent of patching or crack sealing required was scaled based on existing pavement condition. These estimates are listed in Table 3. For mastic patching percent total pavement are values that were assumed, the quantity of mastic patching in $\mathrm{m}^{3}$ was then calculated based on a patch depth of $7.6 \mathrm{~cm}$. The quantity of crack sealing was based on the presence of both longitudinal and transverse cracks. The number of $1.8-\mathrm{m}$ cracks per roadway station was adjusted based on existing pavement condition as shown. Each crack was considered to be $1.3 \mathrm{~cm}$ wide and $2.5 \mathrm{~cm}$ deep. These dimensions were used to calculate the volume of crack sealant required for PaLATE analysis.

\section{Table 3. Dimensions and frequencies used to calculate the volume of localized treatments in one mile of roadway}

\begin{tabular}{|c|c|c|}
\hline \multicolumn{3}{|c|}{ Mastic Patching } \\
\hline Existing Pavement Condition & \multicolumn{2}{c|}{ Percent Total Area } \\
\hline Moderate & $5 \%$ \\
\hline \multicolumn{2}{|c|}{ Poor } & $10 \%$ \\
\hline \multicolumn{2}{|c|}{ Very Poor } & $15 \%$ \\
\hline \multicolumn{2}{|c|}{ Crack Sealing } \\
\hline $\begin{array}{c}\text { Existing Pavement } \\
\text { Condition }\end{array}$ & $\begin{array}{c}\text { Cracks Per Road Station } \\
(30 \text { meters) }\end{array}$ & $\begin{array}{c}\text { Length of Cracks Per } \\
\text { Road Station (m) }\end{array}$ \\
\hline Moderate & 3 & 5.5 \\
\hline Poor & 6 & 11 \\
\hline Very Poor & 10 & 18 \\
\hline
\end{tabular}

4) Environmental impacts from water as a material are not considered in the PaLATE analysis. Only the percent asphalt of the bituminous material in each layer was analyzed. The remainder of the bituminous volume (i.e. the water) was ignored. This allowed for differentiation of the bituminous material used in the treatments. Bituminous material with a higher percentage of asphalt has a greater environmental effect then those with a smaller percentage.

5) Some of the materials were provided as weight as opposed to volume quantities. These materials include asphalt binder (bitumen), virgin aggregate, cement, and sand. PaLATE provides average unit weights. These were used to convert material weights to volumes.

6) The polymer coat solids in the UltraThin Bonded Wearing Course were ignored. PaLATE does not have a parameter for this type of material. Since such small amounts were used, it was determined that the solids could be ignored without affecting the analysis.

\section{Analysis Approach}

Material quantities are input to PaLATE and it generates environmental impacts as outputs. In this analysis, only environmental impacts from the material initial processing were considered. Construction methods, maintenance, and transportation effects are not analyzed. The environmental outputs of each individual material in each layer were calculated. Asphalts from different portions of one treatment were analyzed separately. The analysis procedure is as follows:

Step 1. Calculate the percent volume of asphalt in each bituminous layer (in gal)

Step 2. Convert all material quantities given in per area bases $\left(\mathrm{m}^{2}\right)$ to volumes $\left(\mathrm{m}^{3}\right)$ based on the thicknesses in Table 1 
Step 3. Multiply the material volumes to the appropriate volume for one lane-mile

Step 4. Calculate the volume of localized treatments per one-lane mile from Table 3 quantities.

Step 5. Enter each material into PaLATE spreadsheet's "Initial Cost" page

Step 6. Gather each material's environmental output from "Environmental Results" page

Step 7. Sum the total environmental outputs from each material in each treatment layer

Step 8. Divide the total environmental outputs by the service life of each treatment as stipulated in Table 2 to calculate annualized impacts.

\section{RESULTS AND RECOMMENDATIONS}

The results were analyzed by different methods. The environmental impacts for each treatment were analyzed separately, then comparatively. To compare environmental outputs of different units, such as $\mathrm{MJ}$ of energy versus $\mathrm{kg}$ of water, the results were expressed as a percentage of a base or reference treatment, in this instance chip seal was selected as the reference treatment. Finally, the results were annualized to account for differences in service life between treatments. Based on the selection criteria provided, treatment service lives were dependent on the type of treatment and the overall condition of the existing pavement. These annualized outputs are used to quantify environmental impacts in the MnDOT spreadsheet tool.

\section{Overall Results}

The results of the analysis are summarized in Table 4. In general, the extent of environmental impact is proportional to the amount of material required for a given treatment. The localized treatments required far less material, thus had far less environmental impacts. The mill and HMA layers required the most material, thus had the greatest environmental impacts.

Table 4. Total environmental results for each treatment - non-annualized

\begin{tabular}{|l|l|c|c|c|c|}
\hline Type & Treatment & $\begin{array}{c}\text { Energy } \\
(\mathbf{G J})\end{array}$ & $\begin{array}{c}\text { Water } \\
\text { consumption (kg) }\end{array}$ & $\begin{array}{c}\mathbf{C O}_{2} \\
(\mathbf{k g})\end{array}$ & $\begin{array}{c}\text { RCRA Hazardous } \\
\text { Waste Generated (kg) }\end{array}$ \\
\hline Areal & Chip Seal & 169 & 62 & 10,077 & 2,447 \\
\hline Areal & Double Chip Seal & 326 & 99 & 20,417 & 3,564 \\
\hline Areal & Microsurfacing & 184 & 73 & 10,733 & 2,918 \\
\hline Areal & Cape Seal & 398 & 135 & 24,278 & 5,038 \\
\hline Areal & UltraThin & 415 & 163 & 24,106 & 6,722 \\
\hline Areal & $\begin{array}{l}\text { 5-cm HMA } \\
\text { Overlay }\end{array}$ & 1,037 & 406 & 60,343 & 16,674 \\
\hline Areal & $\begin{array}{l}\text { Mill \& 5-cm HMA } \\
\text { Overlay }\end{array}$ & 1,044 & 406 & 62,428 & 16,729 \\
\hline Local & Crack Sealing & 0.2 & 0.1 & 9.4 & 2.4 \\
\hline Local & Mastic - Moderate & 1.2 & 0.4 & 70.8 & 14.7 \\
\hline Local & Mastic - Severe & 2.3 & 0.8 & 142 & 29.5 \\
\hline
\end{tabular}

Because the results are a variety of catagories that cannot be added, the treatments were compared to a base treatment, which was defined as chip seal for this analysis. The results of the comparison are shows in Figure 1. Most of the areal treatments have greater environmental output then chip seal, with the micro-surfacing providing the most similar environmental impact. The environmental outputs for the HMA and mill \& HMA are far greater than any other treatment. Crack sealing and both levels of mastic have a significantly lower environmental output then the base case. Both localized treatments also have very similar results. 


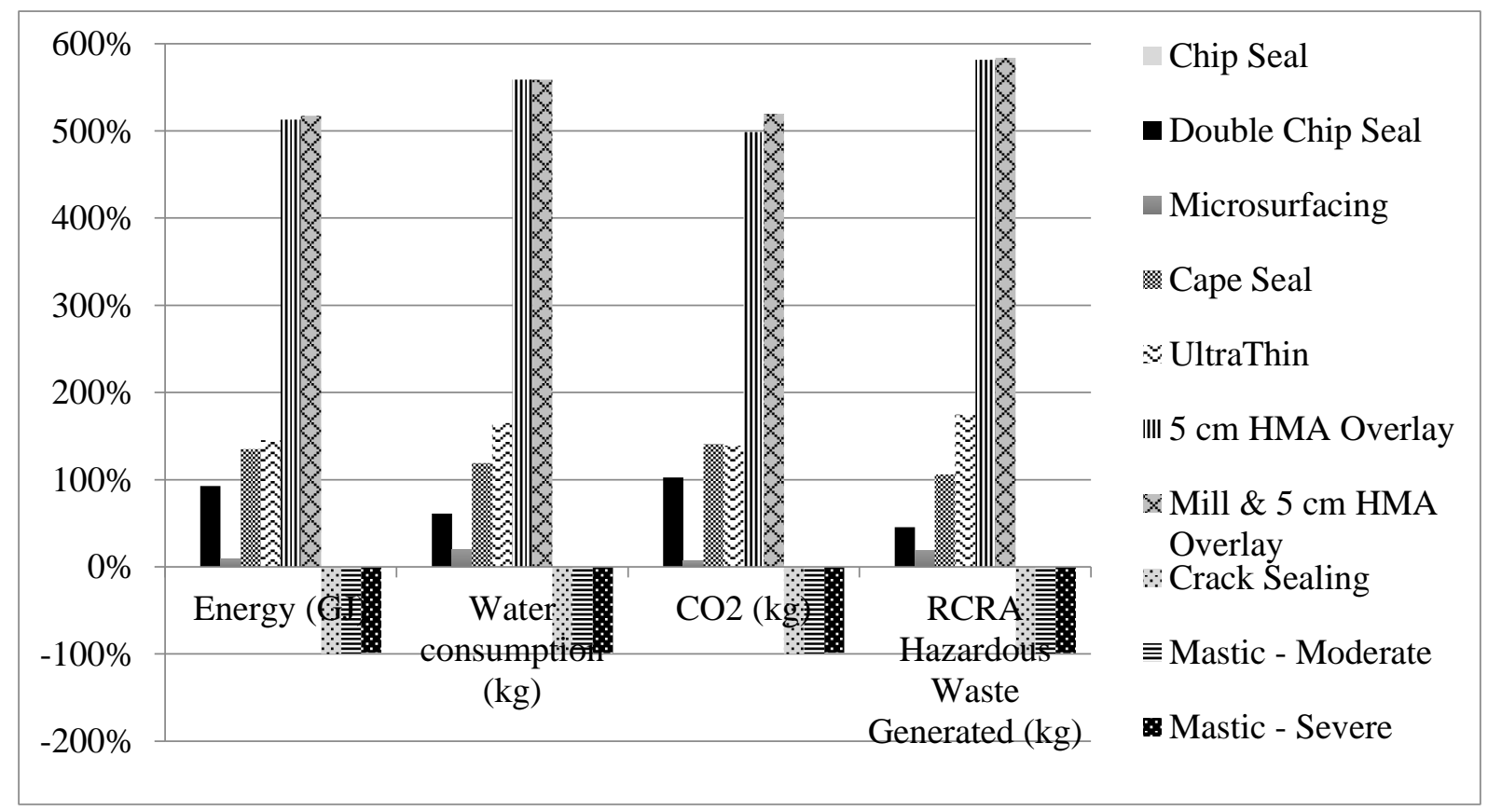

Figure 1. Environmental outputs compared to a base case, chip seal

To more easily discern the least impactful treatment, the treatments were ranked and scored (Table 5). Ranks 1 through 10 were awarded to each treatment for different impact categories, with 10 having the greatest impact and 1 having the least. Impact categories were weighted according to their relevance for impact assessments. Energy and $\mathrm{CO}_{2}$ emission were the two most important categories and were weighted as one times their rank. Water and waste generations considered less critical. These categories were weighted by half of their rank so as to have a smaller influence on the overall score in comparison to energy and emissions. Ranks were multiplied by the appropriate weight to calculate a treatment's score. The treatment with the lowest score would have the smallest environmental effect. The final rank based on the overall score for each treatment is listed in Table 5.

Table 5. Rank of treatment options based on all four impact categories

\begin{tabular}{|c|c|c|c|c|c|c|}
\hline \multirow[t]{2}{*}{ Treatment } & $\begin{array}{c}\text { Energy } \\
\text { (GJ) }\end{array}$ & $\mathrm{CO}_{2}(\mathrm{~kg})$ & Water (kg) & $\begin{array}{l}\text { RCRA Haz } \\
\text { Waste (kg) }\end{array}$ & \multirow{2}{*}{$\begin{array}{l}\text { Total } \\
\text { Score }\end{array}$} & \multirow{2}{*}{$\begin{array}{l}\text { Final } \\
\text { Rank }\end{array}$} \\
\hline & Score $(x 1)$ & Score $(x 1)$ & Score $\left(x^{1 / 2}\right)$ & Score $\left(x^{1} / 2\right)$ & & \\
\hline Chip Seal & 4 & 4 & 2 & 2 & 12 & 4 \\
\hline Double Chip Seal & 6 & 6 & 3 & 3 & 18 & 6 \\
\hline Microsurfacing & 5 & 5 & 2.5 & 2.5 & 15 & 5 \\
\hline Cape Seal & 7 & 8 & 3.5 & 3.5 & 22 & 7 \\
\hline Ultra Thin & 8 & 7 & 4 & 4 & 23 & 8 \\
\hline 5-cm HMA Overlay & 9 & 9 & 4.5 & 4.5 & 27 & 9 \\
\hline $\begin{array}{l}\text { Mill \& 5-cm HMA } \\
\text { Overlay }\end{array}$ & 10 & 10 & 4.5 & 5 & 29.5 & 10 \\
\hline Crack Sealing & 1 & 1 & 0.5 & 0.5 & 3 & 1 \\
\hline Mastic - Moderate & 2 & 2 & 1 & 1 & 6 & 2 \\
\hline Mastic - Severe & 3 & 3 & 1.5 & 1.5 & 9 & 3 \\
\hline
\end{tabular}


The local treatments ranked in the top three positions, with crack sealing with the lowest total score. Of the areal treatments, chip seal ranked the lowest. Both HMA overlay treatments consistently scored highest in all categories, and therefore have the highest total score. This ranking system can be referenced when a user is comparing the absolute environmental impact of multiple treatment options.

\section{Environmental Results by Category}

The individual environmental results are shown in Figure 2 as radar plots. These plots allow for evaluation of the relative severity of the various environmental impacts considered for each treatment. The individual results of each factor are compared for all treatment. The following section discusses comparisons of each individual environmental output.

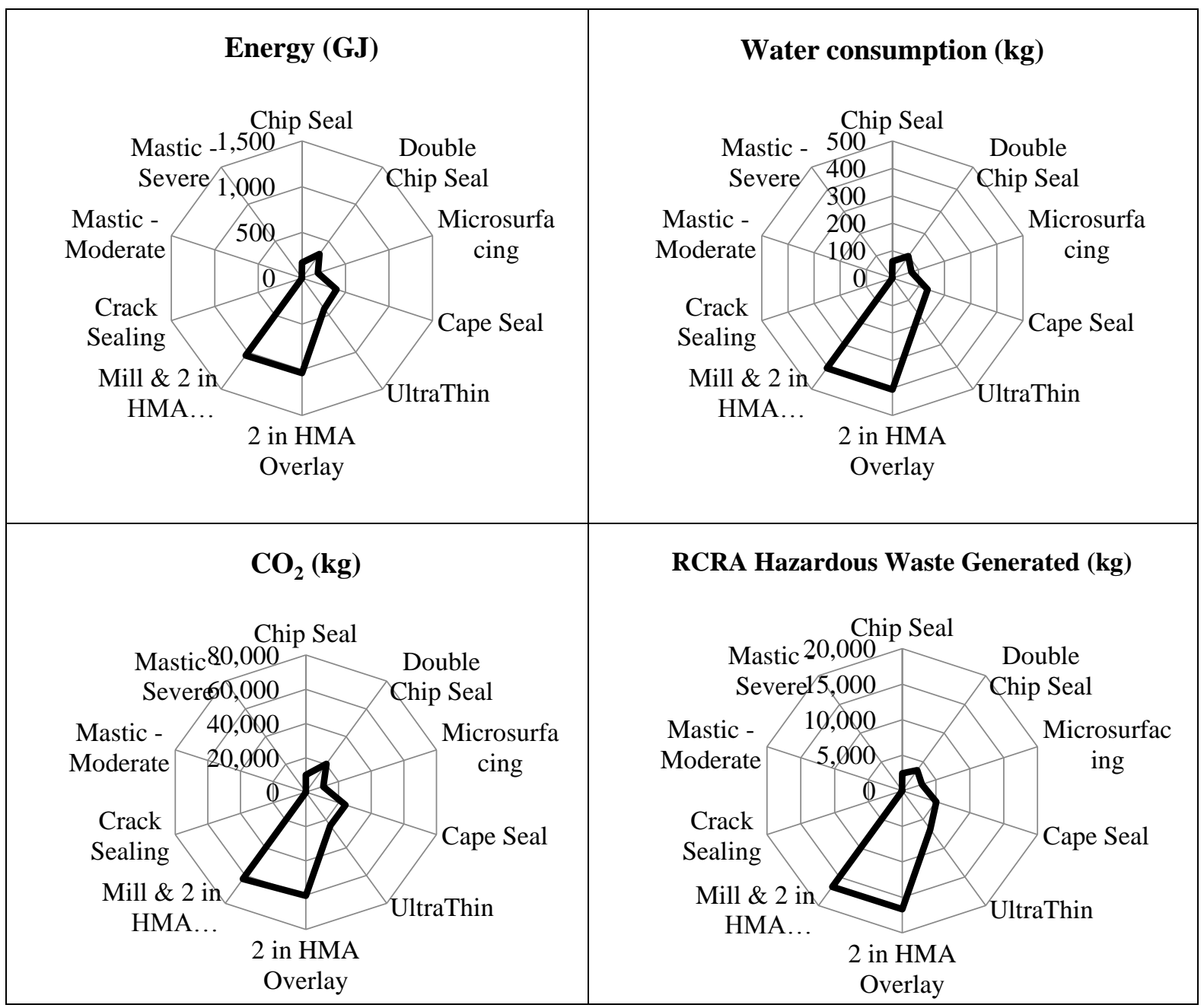

Figure 2. Radar Plot of each treatment results per environmental output.

Energy - The least amount of energy is consumed by the localized treatments, and compared to the other treatments, approaches zero. Of the areal treatments, the chip seal and micro-surfacing have the lowest energy consumption. The mill \& HMA and HMA layers have significantly larger overall energy consumption.

Water consumption - Water requirements follow a similar trend as energy requirements. The localized treatments' water consumption is next to nothing compared to the other treatments. There is less of a gap between the lowest water consumption areal treatments (again chip seal and micro-surfacing), and the highest water consumption areal treatments (again mill \& HMA and HMA). 
$\mathrm{CO}_{2}$ - Carbon dioxide emissions follow a similar trend as energy and water consumptions, with localized treatments emissions comparatively insignificant, chip seal and micro-surfacing the lowest emitting areal treatment, and mill \& HMA and HMA the highest emitting areal treatment. In these results, there is a greater difference in the double chip seal and the cape seal versus the other lowemitting areal treatments.

RCRA Hazardous Waste - The hazardous waste generation trend is also similar to the above three environmental results. However, unlike $\mathrm{CO}_{2}$ emissions, there is less of a difference between the double chip and cape seal as compared to the low-generating chip and micro-surfacing treatments.

\section{Annualized Environmental Impacts}

Because of the differing lifetimes the treatment options and their dependence on the initial road condition, it is important to compare the impacts for a set amount of time. For this purpose, the results were annualized for each possible initial roadway condition (Table 6). Ultimately, the annualized results are used in the evaluation tool.

Table 6. Annualized environmental results per treatment per pavement initial condition for the average service life.

\begin{tabular}{|c|c|c|c|c|c|c|}
\hline & \multicolumn{3}{|c|}{ Energy (GJ/year) } & \multicolumn{3}{|c|}{ Water Consumption (kg/year) } \\
\hline Treatment & Moderate & Poor & $\begin{array}{l}\text { Very } \\
\text { Poor }\end{array}$ & Moderate & Poor & $\begin{array}{l}\text { Very } \\
\text { Poor }\end{array}$ \\
\hline Chip Seal & 38.1 & 127 & $\mathrm{n} / \mathrm{a}$ & 13.9 & 46.2 & $\mathrm{n} / \mathrm{a}$ \\
\hline Double Chip Seal & 59.8 & 95.2 & 245 & 18.2 & 28.9 & 74.4 \\
\hline Microsurfacing & 41.4 & 76.6 & 138 & 16.5 & 30.6 & 55.1 \\
\hline Cape Seal & 72.9 & 116 & 166 & 24.7 & 39.3 & 56.2 \\
\hline UltraThin & 64.2 & 93.3 & 121 & 25.3 & 36.7 & 47.6 \\
\hline 5-cm HMA Overlay & 190 & 302 & 302 & 74.4 & 118 & 118 \\
\hline $\begin{array}{l}\text { Mill \& 5-cm HMA } \\
\text { Overlay }\end{array}$ & 162 & 235 & 305 & 62.8 & 91.3 & 118 \\
\hline Crack Sealing & 0.0 & 0.0 & 0.1 & 0.0 & 0.0 & 0.0 \\
\hline Mastic & 0.2 & 0.3 & 0.7 & 0.1 & 0.1 & 0.2 \\
\hline & \multicolumn{3}{|c|}{$\mathrm{CO}_{2}(\mathrm{~kg} /$ year$)$} & \multicolumn{3}{|c|}{ RCRA Hazardous Waste (kg/year) } \\
\hline Treatment & Moderate & Poor & $\begin{array}{l}\text { Very } \\
\text { Poor }\end{array}$ & Moderate & Poor & $\begin{array}{l}\text { Very } \\
\text { Poor }\end{array}$ \\
\hline Chip Seal & 2,267 & 7,558 & $\mathrm{n} / \mathrm{a}$ & 550 & 1,835 & $\mathrm{n} / \mathrm{a}$ \\
\hline Double Chip Seal & 3,743 & 5,955 & 15,313 & 653 & 1,040 & 2,673 \\
\hline Microsurfacing & 2,415 & 4,472 & 8,050 & 656 & 1,216 & 2,188 \\
\hline Cape Seal & 4,451 & 7,081 & 10,116 & 924 & 1,469 & 2,099 \\
\hline UltraThin & 3,731 & 5,424 & 7,031 & 1,040 & 1,513 & 1,961 \\
\hline 5-cm HMA Overlay & 11,063 & 17,600 & 17,600 & 3,057 & 4,863 & 4,863 \\
\hline $\begin{array}{l}\text { Mill \& 5-cm HMA } \\
\text { Overlay }\end{array}$ & 9,661 & 14,045 & 18,207 & 2,589 & 3,764 & 4,879 \\
\hline Crack Sealing & 1.7 & 2.7 & 7.1 & 0.4 & 0.7 & 1.8 \\
\hline Mastic & 11.0 & 15.9 & 41.3 & 2.3 & 3.3 & 8.6 \\
\hline
\end{tabular}

Users can compare the impacts of multiple treatment options for different pavement conditions. The output of the tool will reveal which option has the lowest annual environmental impact. These results can be combined with an economic analysis to determine the option with the least annual cost and environmental impact. Similar to the overall results, the highest impacts are realized when areal treatments are used, with local treatments impacting the environment significantly less. Even annualized, the HMA overlay options have the highest impacts. 


\section{CONCLUSION}

The results of this analysis and the other tasks contributing to the evaluation tool for short-term treatment of poor pavements are contained in a report by CFIRE (Adams et al., 2014). The deliverables included a spreadsheet tool for evaluating the cost effectiveness and environmental impacts of treatments for pavements in poor condition as well as a user guide for the spreadsheet tool. In the tool, users select the existing pavement distresses, project geometry, traffic characteristics, and daily work zone activity. The tool then determines the pavement's existing condition (moderate, poor, or very poor), treatment area, feasibility and monetary decision factors, qualitative decision factors, and total project costs. Environmental impacts are included in the qualitative decision factors. For the applicable treatments, the tool utilizes the annualized impact results calculated by the RMRC from PaLATE. In practice, most users will find that the localized treatment methods have far lower impacts than the areal treatments, and overlays have the largest impacts of all options.

\section{ACKNOWLEDGEMENTS}

Funding for this project was provided by MnDOT through MnDOT Contract No. 89264 Work Order No.5. Prof. Teresa Adams and Dr. Andrew Hanz of CFIRE assisted in providing data for the environmental analysis, as well as incorporating the results into the final evaluation tool.

\section{REFERENCES}

Adams, T., Bloom, E., Edil, T., Hanz, A., and Schroeckenthaler, K. (2014). "Cost-Effective Means of Managing Pavements in Poor Condition." National Center for Freight \& Infrastructure Research and Education (CFIRE), CFIRE 05-0, MnDOT Contract No. 89264 Work Order No.5, <http://www.wistrans.org/cfire/research/projects/05-03/> (Dec. 12, 2015)

DeCorla-Souza, P., Everett, J., Gardner, B., and Culp, M. (1997). "Total cost analysis: An alternative to benefit-cost analysis in evaluating transportation alternative." Transportation, 107-123.

Federal Highway Administration (FHWA). (2011). "Work Zone Road User Costs: Concepts and Applications." U.S. Department of Transportation, Federal Highway Administration, FHWA-HOP12-005. <http://www.ops.fhwa.dot.gov/wz/resources/publications/fhwahop12005/

fhwahop12005.pdf> (Mar. 20, 2016).

Horvath, A. (2007). "PaLATE: Pavement Life-cycle Assessment Tool for Environmental and Economic Effects." Consortium on Green Design and Manufacturing, University of California, Berkeley, <http://www.ce.berkeley.edu/ horvath/palate.html> (Mar. 28, 2014).

Minnesota Department of Transportation. (2014). "Minnesota State Highway Investment Plan: 20142033." Minnesota Department of Transportation, <http://www.dot.state.mn.us/planning/mnship/> (March 20, 2016).

Janisch, D., and Gaillard, F. (1998). Minnesota Seal Coat Handbook. Report MN/RC-1999-07. Minnesota Local Road Research Board, Minnesota DOT, St. Paul.

Johnson, G. (2003). "Minnesota's experience with thin bituminous treatments for low-volume roads." Transportation Research Board, 1819, 333-337.

U.S. Environmental Protection Agency (EPA). (2015). "Resource Conservation and Recovery Act (RCRA) Laws and Regulations." EPA, <http://www.epa.gov/rcra> (Dec. 7, 2015). 